\title{
Konsep Desa Wisata: Pengembangan Potensi Desa, Pelestarian Agama, Budaya dan SDM
}

\author{
I Made Putra Aryana \\ Fakultas Dharma Acarya IHDN Denpasar \\ Email: madeputra84@gmail.com
}

\begin{abstract}
Abstrak
Strategi pemerintah untuk mengatasi ketimpangan pembangunan di perkotaan dan pedesaan adalah dengan menaruh perhatian besar terhadap pembangunan daerah perdesaan. Desa diberikan otonomi untuk mengatur dan mengurus kepentingan masyarakat. Upaya yang dilakukan desa untuk meningkatkan taraf hidup masyarakatnya adalah membentuk desa wisata. Melalui literasi dan studi kepustakaan, diuraikan usaha-usaha yang dapat dilakukan untuk pengembagan desa wisata. Usaha Daya Tarik Wisata adalah upaya atau kegiatan yang mempergunakan sesuatu yang memiliki keunikan, keindahan dari alam maupun budaya yang dimiliki oleh masyarakat yang menjadi sasaran tertentu guna untuk kunjungan wisatawan. Setiap desa memiliki potensi untuk dijadikan komoditas wisata unggulan. Pemerintah Daerah Bali telah menetapkan bahwa pariwisata yang dikembangkan di daerah Bali adalah Periwisata Budaya. Pariwisata budaya adalah jenis kepariwisataan yang berkembang dan perkembangannya menggunakan kebudayaan daerah Bali yang dijiwai oleh agama Hindu. Sebesar apa pun dan sebagus apa pun potensi yang akan menjadi komoditas unggulan jika pelaku usaha pariwisata (desa) tidak siap dengan ilmu manajemen pariwisata, maka bisa dipastikan kegiatan pariwisata itu tak akan berlangsung lama.
\end{abstract}

Kata kunci: desa wisata, potensi desa, agama adat dan budaya, SDM

\begin{abstract}
Abstrack
The government's strategy to overcome development inequality in urban and rural areas is to pay great attention to rural development. Villages are given autonomy to regulate and manage community interests. The effort made by the village to improve the standard of living of its people is to form a tourism village. Through literacy and literature study, efforts can be made to develop tourism villages. Tourist Attraction Business is an effort or activity that uses something that is unique, the beauty of nature and culture that is owned by the community which is a particular target for tourist visits. Every village has the potential to become a leading tourism commodity. The Regional
\end{abstract}


Government of Bali has determined that tourism developed in the area of Bali is Cultural Tourism. Cultural tourism is a type of tourism that develops and develops using Balinese culture inspired by Hinduism. As much as anything and as good as the potential that will become a superior commodity if tourism business actors (villages) are not ready with the science of tourism management, then we can be sure that tourism activities will not last long.

\section{Keywords: tourism village, village potential, indigenous religion and culture, Human Resources}

\section{Pendahuluan}

Berdasarkan data BPS pada September 2015 yang diuraikan dalam ejournal.lipi.go.id/ bahwa tingkat kemiskinan di perkotaan sebesar 8,22\% sedangkan tingkat kemiskinan di perdesaan mencapai 14,09\%. Menghadapi persoalan tersebut, strategi pemerintah untuk mengatasi ketimpangan pembangunan nasional dengan menaruh perhatian besar terhadap pembangunan daerah perdesaan. Dalam hal ini, desa diberikan otonomi untuk mengatur dan mengurus kepentingan masyarakat berdasarkan hak asal-usul, adat istiadat, dan nilai sosial budaya masyarakat desa, serta menetapkan dan mengelola kelembagaan desa. Tentunya untuk menjalankan kesemuanya itu maka pemerintah desa perlu mendapatkan dukungan dana. Dana tersebut diperoleh dari sumber-sumber pendapatan desa meliputi PADesa (Pendapatan Asli Desa), alokasi APBN (Anggaran Pendapatan Belanja Negara), bagian dari PDRD kabupaten/ kota, ADD (Alokasi Dana Desa), bantuan keuangan dari APBD provinsi/kabupaten/kota, hibah dan sumbangan pihak ketiga, dan lain-lain pendapatan yang sah. Ini bertujuan supaya pemerintah desa dapat memberikan pelayanan prima dengan memberdayakan masyarakat untuk berpartisipasi aktif dalam program kegiatan pembangunan baik fisik maupun non fisik sehingga tercapai pembangunan dan peningkatan kesejahteraan masyarakat desa.

Upaya yang dilakukan desa untuk meningkatkan taraf hidupmasyarakatnya adalah membentuk desa wisata. Biasanya permasalahan mainstream dari suatu desa yang memiliki potensi wisata seperti infrastruktur jalan, jembatan, listrik, pipanisasi air, jaringan komunikasi dan lain-lain. Selain itu permasalahan bisa juga bersifat non fisik, tapi bersifat sosial. Misalnya, bisa saja desa tersebut memiliki potensi keindahan alam namun dari sisi keamanannya kurang. Penanganan permasalahan sosial ini memerlukan pendekatan multidimensi tertentu yang tepat.

Tidak sedikit komitmen tidak terbangun dengan kuat untuk menyamakan visi misi untuk menjadikan desa wisata. Ini tidak terlepas dari kekhawatiran terhadap dampak yang bisa terjadi dari kegiatan pariwisata. Sebagian komponen desa mungkin melihat contoh daerah lain yang dianggap gagal sebagai desa wisata karena menimbulkan dampak negatif misalnya menurunnya moralitas generasi muda desa, atau dampak lingkungan yang terjadi karena pembangunan fisik besar-besaran sarana 
penunjang wisata desa yang tanpa memperhatikan aspek lingkungannya, misal terjadi banjir atau tanah longsor di kawasan wisata alam

Setiap desa memiliki potensi untuk dijadikan komoditas wisata unggulan. Keindahan dan keunikan alam akan menjadi wisata alam. Jika desa tersebut memiliki keunikan tradisi dan budayanya bisa menjadi destinasi wisata budaya. Jika desa tersebut memiliki menu makanan dan minuman khas tradisional yang unik baik dari bahan, rasa dan penyajiannya, bisa dijadikan destinasi wisata kuliner desa. Jika desa tersebut memiliki kerajinan-kerajinan khas nan unik bisa menjadi destinasi wisata suvenir desa. Atau jika desa tersebut memiliki peninggalan-peninggalan yang mempunyai nilai sejarah yang tinggi atau situs sejarah/prasejarah bisa menjadi tujuan wisata sejarah desa. Dunia wisata dalam kekinian banyak mengalami perkembangan yang cukup signifikan. Apapun bisa dijadikan wisata yang mendatangkan keuntungan ekonomi bagi warga sekitar, asal jeli melihat dan memanfaatkan peluang.

Perlu peran Pemerintah Daerah untuk membangun potensi desa menjadi desa wisata. Melalui dinas-dinas terkait, perangkat-perangkat baik berupa regulasi, perijinan, pajak dan sebagainya sehingga secara hirarkis administratif desa wisata berada di bawah pembinaan dan tanggung jawab Pemerintah. Untuk menjadi desa wisata diperlukan perangkat regulasi/norma sebagai aspek legalitas dan yuridis formal. Dengan memiliki dasar hukum yang jelas dan kuat, desa wisata diharapkan dapat beraktivitas tanpa ada gangguan misalnya keberatan dari pihak-pihak lain

\section{Pembahasan}

Otonomi daerah di Indonesia (sejak 2001) telah membuka ruang bagi pemerintah daerah untuk bertanggung jawab dalam mengurus urusan rumah tangganya sendiri. Ini merupakan solusi alternatif dalam mengatasi berbagai persoalan yang terjadi karena masalah ketimpangan pembangunan baik antara pusat dan daerah maupun antardaerah kabupaten dan kota. Ketidakseimbangan yang terjadi sebagai akibat pembangunan yang tidak merata hingga menyebabkan tingginya angka kemiskinan di Indonesia (NL Aziz, 2017 dalam ejournal.lipi).

Salah satu wujud perhatian pemerintah dengan disahkannya Undang-undang Nomor 6 Tahun 2014 tentang Desa. UU ini membawa perubahan besar yang mendasar bagi kedudukan dan relasi desa dengan daerah dan pemerintah meliputi aspek kewenangan, perencanaan, pembangunan, keuangan dan demokrasi desa. Melalui UU ini, kedudukan desa menjadi lebih kuat. UU ini dengan jelas menyatakan bahwa desa dan desa adat mendapat perlakuan yang sama dari pemerintah dan pemerintah daerah.

Desa diberikan otonomi untuk mengatur dan mengurus kepentingan masyarakat berdasarkan hak asal-usul, adat istiadat, dan nilai sosial budaya masyarakat desa, serta menetapkan dan mengelola kelembagaan desa. Tentunya untuk menjalankan kesemuanya itu maka pemerintah desa perlu mendapatkan dukungan dana. Dana tersebut diperoleh dari sumber-sumber pendapatan desa meliputi PADesa (Pendapatan Asli Desa), alokasi APBN (Anggaran Pendapatan Belanja Negara), bagian dari PDRD kabupaten/ kota, ADD (Alokasi Dana Desa), bantuan keuangan dari APBD provinsi/kabupaten/kota, hibah dan sumbangan pihak ketiga, dan lain-lain pendapatan yang sah. Ini bertujuan supaya pemerintah desa dapat memberikan pelayanan prima 
dengan memberdayakan masyarakat untuk berpartisipasi aktif dalam program kegiatan pembangunan baik fisik maupun non fisik sehingga tercapai pembangunan dan peningkatan kesejahteraan masyarakat desa.

Desa mempunyai hak untuk mengelola kewenangan dan pendanaannya sendiri. Dengan demikian, ini menjadi tugas dan catatan penting tidak hanya bagi pemerintah serta masyarakat untuk membangun desa secara kolektif. Pembangunan dapat diartikan sebagai upaya meningkatkan kemampuan manusia untuk memengaruhi masa depannya. Ada lima implikasi utama dari pembangunan (NL Aziz, 2017 dalam ejournal.lipi) yakni: (a) capacity, pembangunan berarti membangkitkan kemampuan optimal manusia, baik individu maupun kelompok; (b) equity, mendorong tumbuhnya kebersamaan dan kemerataan nilai dan kesejahteraan; (c) empowerment, menaruh kepercayaan kepada masyarakat untuk membangun dirinya sendiri sesuai dengan kemampuan yang ada padanya. Kepercayaan dalam bentuk kesempatan yang sama, kebebasan memilih dan kekuasaan dalam memutuskan; (d) sustainability, membangkitkan kemampuan untuk membangun secara mandiri; dan (e) interdependence, mengurangi ketergantungan negara yang lain dan menciptakan hubungan saling menguntungkan dan saling menghormati. Ketidakmerataan pembangunan yang terjadi di Indonesia antara kawasan perkotaan dan perdesaan memiliki gap yang tinggi sehingga pembangunan pedesaan menjadi jauh tertinggal dibanding perkotaan. Oleh karena itu, fokus perhatian pemerintahan saat ini adalah bagaimana membangun desa menjadi desa yang otonom dan mandiri, salah satunya melalui pemberian dana desa, yang dikembangkan oleh desa untuk membangun desa wisata.

Potensi wisata yang luar biasa yang dimiliki seharusnya bisa menjadi andalan untuk mengangkat taraf hidup masyarakat. Di era yang semakin maju semakin pula banyak cara dan strategi untuk mengangkat potensi wisata di suatu daerah. Masingmasing daerah memiliki kekhasan atau penonjolan karakteristik alam maupun sosio kultural dan aspek lainnya. Desa memiliki segudang potensi bisnis yang menguntungkan untuk bisa diangkat menjadi komoditas dan dipoles dengan manajemen strategi yang tepat untuk menjadi desa wisata. Berikut langkah-langkah strategis untuk mengembangkan potensi desa menjadi desa wisata (diunduh dari www.berdesa.com):

1. Identifikasi potensi desa melalui rembug bersama seluruh komponen desa dari semua kalangan. Potensi yang bisa menjadi komoditas bisa bermacam-macam dari segala aspek. Bisa keindahan alam, hasil bumi, kekayaan flora fauna/hayati, sosio kultural, masyarakat, tradisi atau hal-hal yang bersifat khas/unik yang tak dimiliki daerah lain. Pastikan potensi unggulan yang akan dijadikan komoditas utama.

2. Identifikasi permasalahan yang bisa jadi penghambat bagi pengembangan potensi wisata desa, mulai dari yang bersifat fisik, non fisik atau sosial, internal dan eksternal. Atau bisa saja permasalahan tersebut jika diolah dengan cara tertentu justru permasalahan itu bisa menjadi potensi.

3. Perlunya komitmen yang kuat dari seluruh komponen desa untuk menyamakan pendapat, persepsi dan mengangkat potensi desa guna dijadikan desa wisata. 
Komitmen ini yang menjadi dukungan terkuat bagi terwujudnya dan keberlangsungan desa wisata

4. Identifikasi dampak baik dampak positif maupun negatif dari sebuah kegiatan wisata sesuai kekhasan masing-masing desa. Masing-masing desa memiliki karakteristik sendiri akan menghasilkan dampak yang juga berbeda satu sama lain terutama perubahan-perubahan sosial cultural.

5. Komitmen yang kuat dari seluruh komponen desa untuk menggandeng Pemerintah Daerah dan jika perlu menggandeng pihak swasta. Pikirkan dan identifikasi juga dampak jika bekerja sama dengan pihak swasta. Termasuk di sini untuk penganggaran guna pembangunan desa wisata dengan menggunakan seluruh sumber daya ekonomi yang ada.

6. Menyiapkan segala perangkat-perangkat aturan/regulasi norma yang lebih bertujuan untuk mengawal pengembangan desa wisata dan mengawasi potensipotensi penyimpangan yang mungkin saja bisa terjadi. Regulasi disiapkan agar berjalannya aktivitas wisata beserta dampaknya tetap berada dalam koridor regulasi sebagai payung hukumnya

7. Melakukan pelatihan-pelatihan bagi seluruh komponen desa, termasuk pemerintah desa tentang manajemen pariwisata, bagaimana mengelola tempat wisata, manajemen tamu/pengunjung, beserta inovasi-inovasi yang perlu dikembangkan mengingat sebagaimana sektor lainnya sektor pariwisata pun mengalami fluktuasi dan bisa mengalami "kejenuhan".

8. Gunakan segala media untuk memperkenalkan dan mempublikasikan potensi wisata di desa baik media konvensional maupun non konvensional, seperti media internet. Internet kini menjadi sarana publikasi yang sangat efektif yang bisa menjangkau seluruh belahan bumi. Tempat wisata yang lokasinya terpencil pun bisa diketahui oleh orang di belahan dunia lain pun berkat teknologi internet

9. Belajar pada kesuksesan desa wisata lain atau studi banding. Kita bisa belajar banyak pada keberhasilan desa wisata lain khususnya yang sejenis. Karena tipikal permasalahan dan tantangan masa depan yang bakal dihadapi kurang lebih sama. Hanya dengan manajemen profesional dan inovatif saja desa wisata akan eksis dan kompetitif dan dapat melalui ujian yang bersifat internal, eksternal maupun regional internasional.

Usaha Daya Tarik Wisata adalah upaya atau kegiatan yang mempergunakan sesuatu yang memiliki keunikan, keindahan dari alam maupun budaya yang dimiliki oleh masyarakat yang menjadi sasaran tertentu guna untuk kunjungan wisatawan.Berdasarkan UU No.9 Tahun 1990 dijelaskan bahwa pengertian kawasan wisata adalah suatu kawasan yang mempunyai luas tertentu yang dibangun dan disediakan untuk kegiatan pariwisata. Apabila dikaitkan dengan pariwisata air, pengertian tersebut berarti suatu kawasan yang disediakan untuk kegiatan pariwisata dengan mengandalkan obyek atau daya tarik kawasan perairan. Berdasarkan UndangUndang Republik Indonesia No. 10 tahun 2009, Daya Tarik Wisata dijelaskan sebagai segala sesuatu yang memiliki keunikan, kemudahan, dan nilai yang berupa keanekaragaman kekayaan alam, budaya, dan hasil buatan manusia yang menjadi 
sasaran atau kunjungan wisatawan (Modul Daya Tarik Wisata, Jurusan Biologi Fakultas Mipa dan IPA Unud).

Lebih lanjut diuraikan pembagian usaha daya tarik wisata, sebagai berikut:

1. Daya tarik wisata alam: flora fauna, keunikan dan kekhasan ekosistem, misalnya eksistem pantai dan ekosistem hutan bakau, gejala alam: misalnya kawah, sumber air panas, air terjun dan danau. Budidaya sumber daya alam, misalnya sawah, perkebunan, peternakan, usaha perikanan.

2. Daya tarik wisata sosial budaya: museum, peninggalan sejarah, upacara adat, seni pertunjukan dan kerajinan.

3. Daya tarik wisata minat khusus merupakan jenis wisata yang baru dikembangkan di Indonesi. Wisata ini lebih diutamakan pada wisatawan yang mempunyai motivasi khusus. Biasanya para wisatawan harus memiliki keahlian: berburu, mendaki gunung, arung jeram, tujuan pengobatan, agrowisata.

Diuraikan pula syarat-syarat untuk menjadi daerah daya tarik wisata

1. What to see. Di tempat tersebut harus ada objek dan atraksi wisata yang berbeda dengan yang dimiliki daerah lain. Dengan kata lain daerah tersebut harus memiliki daya tarik khusus dan atraksi budaya yang dapat dijadikan "entertainment" bagi wisatawan. What to see meliputi pemandangan alam, kegiatan, kesenian dan atraksi wisata. Maksudnya adalah sesuatu yang menarik untuk dilihat.

2. What to do. Di tempat tersebut selain banyak yang dapat dilihat dan disaksikan, harus disediakan fasilitas rekreasi yang dapat membuat wisatawan betah tinggal lama ditempat itu. Maksudnya adalah sesuatu aktivitas yang dapat dilakukan di tempat itu.

3. What to buy. Tempat tujuan wisata harus tersedia fasilitas untuk berbelanja terutama barang souvenir dan kerajinan rakyat sebagai oleh-oleh untuk di bawa pulang ke tempat asal.

4. What to arrived. Di dalamnya termasuk aksesbilitas, bagaimana kita mengunjungi daya tarik wisata tersebut, kendaraan apa yang akan digunakan dan berapa lama tiba ketempat tujuan wisata tersebut.

5. What to stay. Bagaimana wisatawan akan tingggal untuk sementara selama dia berlibur. Diperlukan penginapan-penginapan baik hotel berbintang atau hotel non berbintang dan sebagainya.

Selain itu pada umunya daya tarik wisata suatu objek wisata berdasarkan atas: 1. Adanya sumber daya yang dapat menimbulkan rasa senang, indah, nyaman dan bersih. 2. Adanya aksesibilitas yang tinggi untuk dapat mengunjunginya. 3. Adanya ciri khusus atau spesifikasi yang bersifat langka. 4. Adanya sarana dan prasarana penunjang untuk melayani para wisatawan yang hadir. 5. Punya daya tarik tinggi karena memiliki nilai khusus dalam bentuk atraksi kesenian, upacara upacara adat, nilai luhur yang terkandung dalam suatu objek buah karya manusia pada masa lampau.

Suatu daerah dikatakan memiliki daya tarik wisata bila memiliki sifat: a. Keunikan, contoh: bakar batu (di Papua) sebuah cara masak tradisional mulai dari upacara memotong hewan (babi) sampai membakar daging, sayuran dan umbi/talas yang disekam dalam lubang, ditutup batu lalu dibakar, serta keunikan cara memakan 
masakan tersebut. b. Keaslian, alam dan adat yang dilakukan sehari -hari, dalam berpakaian dan kehidupan keluarga dimana seorang perempuan lebih mengutamakan menggendong babi yang dianggapnya sangat berharga dari pada menggendong anak sendiri. c. Kelangkaan, sulit ditemui di daerah/negara lain d. Menumbuhkan semangat dan memberikan nilai bagi wisata.

Pembangunan suatu objek wisata harus dirancang dengan bersumber pada potensi daya tarik yang dimiliki objek tersebut dengan mengacu pada cerita keberhasilan pengembangan yang meliputi berbagai kelayakan (Modul Daya Tarik Wisata, Jurusan Biologi Fakultas Mipa dan IPA Unud). yaitu:

1. Kelayakan Finansial. Studi kelayakan ini menyangkut perhitungan secara komersial dan pembangunan objek wisata tersebut. Perkiraan untung-rugi sudah harus diperkirakan dari awal. Berapa tenggang waktu yang dibutuhkan untuk kembali modal pun sudah harus diramalkan.

2. Kelayakan Sosial Ekonomi Regional. Studi kelayakan ini dilakukan untuk melihat apakah investasi yang ditanamkan untuk membangun suatu objek wisata juga akan memiliki dampak sosial ekonomi secara regional; dapat menciptakan lapangan kerja berusaha, dapat meningkatkan penerimaan devisa, dapat meningkatkan penerimaan pada sektor yang lain seperti pajak, perindustrian, perdagangan, pertanian, dan lain sebagainya. Dalam kaitannya dengan hal ini pertimbangan tidak semata-mata komersial saja tetapi juga memperhatikan dampaknya secara lebih luas.

3. Layak Teknis. Pembangunan objek wisata harus dapat dipertanggungjawabkan secara teknis dengan melihat daya dukung yang ada. Tidaklah perlu memaksakan diri untuk membangun suatu objek wisata apabila daya dukung objek wisata tersebut rendah. Daya tarik suatu objek wisata tersebut membahayakan keselamatan para wisatawan.

4. Layak Lingkungan. Analisis dampak lingkungan dapat dipergunakan sebagai acuan kegiatan pembangunan suatu objek wisata. Pembangunan objek wisata yang mengakibatkan rusaknya lingkungan harus dihentikan pembangunannya. Pebangunan objek wisata bukanlah untuk merusak lingkungan, tetapi sekedar memanfaatkan sumber daya alam untuk kebaikan manusia dan untuk meningkatkan kualitas hidup manusia sehingga terciptanya keseimbangan, keselarasan, dan keserasian hubungan antara manusia dengan lingkungan alam dan manusia dengan Tuhannya.

Setiap desa memiliki potensi untuk dijadikan komoditas wisata unggulan. Keindahan dan keunikan alam akan menjadi wisata alam. Jika desa tersebut memiliki keunikan tradisi dan budayanya bisa menjadi destinasi wisata budaya. Jika desa tersebut memiliki menu makanan dan minuman khas tradisional yang unik baik dari bahan, rasa dan penyajiannya, bisa dijadikan destinasi wisata kuliner desa. Jika desa tersebut memiliki kerajinan-kerajinan khas nan unik bisa menjadi destinasi wisata suvenir desa. Atau jika desa tersebut memiliki peninggalan-peninggalan yang mempunyai nilai sejarah yang tinggi atau situs sejarah/prasejarah bisa menjadi tujuan wisata sejarah desa. Bahkan jika desa itu memiliki keunggulan hasil bumi atau hasil 
laut misalnya pertanian, perkebunan, perikanan dan lain-lain (contoh wisata petik bunga gumitir, petik strawberry, petik tomat, cabai dan sayuran lain). Dunia wisata dalam kekinian banyak mengalami perkembangan yang cukup signifikan. Apapun bisa dijadikan wisata yang mendatangkan keuntungan ekonomi bagi warga sekitar, asal jeli melihat dan memanfaatkan peluang.

Pemerintah Daerah Bali telah menetapkan bahwa pariwisata yang dikembangkan di daerah Bali adalah Periwisata Budaya. Pariwisata budaya adalah jenis kepariwisataan yang berkembang dan perkembangannya menggunakan kebudayaan daerah Bali yang dijiwai oleh agama Hindu yang merupakan bagian dari kebudayaan nasional sebagai potensi dasar yang paling dominan, yang didalamnya tersirat satu cita-cita akan adanya hubungan timgal balik antara pariwisata dengan kebudayaan, sehingga keduanya meningkat secara serasi, selaras dan seimbang. Pelaksanaan pariwisata budaya berdasarkan azas mufakat, usaha bersama dan kekeluargaan, adil dan merata, percaya pada diri sendiri dan perikehidupan keseimbangan, keserasian dan keselarasan yang berpedoman kepada falsafah Tri Hita Karana (Astawa, 2016: 61-72).

Lebih lanjut dijelaskan tujuan pelaksanaan penyelenggaraan pariwisata budaya bertujuan untuk: (1). Memperkenalkan, mendayagunakan, melestarikan dan meningkatkan mutu objel dan daya tarik wisata, (2). Memupuk rasa cinta tanah air dan meningkatkan persahabatan antar bangsa, (3), memperluas an memeratakan kesempatan berusaha dan lapangan pekerjaan, (4). Meningkatkan pendapatan daerah dalam rangka meningkatkan kesejahteraan dan kemakmuran rakyat, (5). Mendorong pendayagunaan produksi daerah dalam rangka meningkatkan produksi nasional, (6). Mempertahankan norma-norma dan nilai-nilai kebudayaan, agama dan keindahan alam Bali yang berwawasan lingkungan hidup, dan (7). Mencegah dan meniadakan pengaruh-pengaruh negative yang dapat ditimbulkan oleh kegiatan-kegiatan kepariwisataan.

Anom (2010:121) menekankan pariwisata berkelanjutan terfokus pada tiga hal, yaitu: kualitas, yang menyangkut kualitas pelayanan kepada masyarakat, peningkatan kualitas atau taraf hidup masyarakat local, dan peningkatan kualitas alam yang dijadikan objek atau daya tarik wisata, (2). Kelestarian sumber daya alam dan kelestarian budaya-budaya masyarakat local dan (3). Keseimbangan kebutuhan industry pariwisata, lingkungan dan masyarakat local agar tercipta tujuan dan kerja sama yang saling menguntungkan diantara para stakeholder dan destinasi pariwisata.

Dalam Prosiding KS: Riset \& PKM disebutkan jaminan bahwa masyarakat harus terlibat di dalam pengembangan desa agar program pengembangan desa wisata berjalan sesuai dengan kebutuhan masyarakat. Jaminan itu dirumuskan dalam hal-hal sebagai berikut:

1. Pengembangan desa wisata harus berpedomanan pada kebudayaan local masyarakat;

2. Masyarakat lokal menjadi sentral dan menjadikan subjek dari semua proses pengembangan desa wisata. Dengan menempatkan masyarakat sebagai sentral 
diharapkan partisipasi masyarakat sebagai pemilik sumber daya pariwisata akan terdorong dan mampu menyejahterakan masyarakat local;

3. Pengembangan desa wisata membutuhkan adanya kemitraan yang solid antara tiga unsur utama, yaitu pemerintah, swasta, dan lembaga, yang masyarakat lokal menjadi pemangku kepentingan dari kerja sama tersebut;

4. Ketiga pemangku kepentingan tersebut berada pada posisi yang sejajar dalam melakukan kerja sama serta saling menghormati;

5. Perlu dibentuk badan pengelola yang otonom dan mandiri, yang saling berinteraksi, memberikan umpan balik pelaksanaan untuk mengoreksi diri pada setiap jenjang organisasi;

6. Keputusan dan inisiatif untuk memenuhi kebutuhan masyarakat lokal dibuat ditingkat lokal oleh warga masyarakat yang memiliki identitas yang diakui peranannya sebagai partisipan dalam proses pengambilan keputusan; dan

7. Fokus utama pengembangan desa wisata adalah memperkuat kemampuan masyarakat lokal dalam mengarahkan dan mengatasi aset-aset yang ada pada masyarakat local untuk memenuhi kebutuhannya. Pelaksanaan hubungan antar pemangku kepentingan tersebut terarah, peran dan tanggung jawab masingmasing harus jelas. Peran dan kewenangan masing-masing pemangku kepentingan sebagai berikut. Peran dan Kewenangan Pemerintah, yaitu (1) melakukan pembinaan kualitas produk dan kemasan kerajinan dan kuliner khas desa sebagai unsur kenangan wisata; (2) melakukan penataan dan konservasi lingkungan fisik kawasan yang menjadi ciri khas desa wisata; (3) melakukan perbaikan/pengadaan infrastruktur persampahan dan sanitasi; (4) melakukan gerakan masyarakat untuk mewujudkan sapta pesona; (5) melakukan pembuatan informasi dan fasilitas kepariwisataan; (6) melakukan perbaikan/peningkatan kualitas ruang publik, pedestrian dan landscape desa/lingkungan untuk mendukung sapta pesona; dan (7) dukungan pemberdayaan terhadap kelompok sadar wisata (Pokdarwis) dalam pelestarian lingkungan pariwisata (kawasan Hutan, dan sawah).

Pitana (2015) dalam "Hospitality Indutry and Tourism Education (The case of Indonesia)" menyatakan "Tourism has been one of the biggest industries in tehe world, seen from varios indicators, such as labor absorption, people movement, and income earned. For a number of countries and territories, tourism has been the biggest contributor in the formation of their gross domestics products". Industry pariwisata merupakan salah satu industry terbesar di dunia karena banyak menyerap tenaga kerja, meningkatkan pendapatan bahkan memberikan kontribusi terbesar pada produk domestic bruto suatu negara. Sector pariwisata merupakan salah satu lokomotif perekonomian Bali dan merupakan sumber Pendapatan Asli Daerah (PAD) khususnya dari pajak dan restoran. Untuk itu, agar pembangunan pariwisata Bali bisa berkelanjutan, peningkatan kualitasnya harus terus diupayakan dengan mepenyesuaikan dengan potensi daerah yang bersinergi dengan sector lain maupun dengan koordinasi yang baik antar kabupaten/kota di Bali serta semua Stakeholders pariwisata (Anom, dkk, 2010:3-4). 
Perencanaan termasuk perencanaan pariwisata harus mempertimbangkan struktur masyarakat yang meliputi: struktur social seperti tingkat pendidikan masyarakat, budaya masyarakat seperti agama, adat- istiadat, keadaan ekonomi masyarakat (mata pencaharian, tingkat pendapatan) agar perencanaan tersebut tidak menimbulkan permasalahan kesenjangan social, degradasi budaya, ketimpangan pendapatan, pengangguran, sebagai akibat keterpinggiran masyarakat local oleh dominasi investor. Demikian juga halnya pemerintah dalam melakukan perencanaan pariwisata harus mampu mengakomodasi agar tercita keharmonisan masyarakat dengan investor dengan tetap memenuhi dan memuaskan kebutuhan wisatawan.

Penelitian Pitana (2000) tentang "Daya Dukung Bali dalam Kepariwisataan (Kajian dari Aspek Lingkungan dan Sosial Budaya)" menyatakan: (1). Apabila laju pertumbuhan penduduk maupaun kehadiran dari imigran tidak dapat dikendalikan maka daya tampung wisatawan akan semakin menurun karena telah mengalami krisis sumber daya lahan dan air, (2). Masyarakat Bali Sangat welcome terhadapat kehadira wisatawan dan dari segi social budaya kehadiran wisatawan masih dapat ditingkatkan jumlahnya sepanjang kehadiran imigran luar daerah dapat dikendalikan, khususnya imigran yang tidak memiliki keterampilan, (3). Sarana akomodasi (kamar) yang tersdia untuk kebutuhan wisatawan sudah mencukupi dan bahkan letah melampaui kebutuhan, yang memungkinkan dikembangkan hanya pondok wisata/homestay, yang ada di pedesaan. Hal yang perlu diupayakan adalah peningkatan diversifikasi objek dan daya tarik wisata yang lebih banyak menampilkan produk local dan kearifan local, dengan tetap menjaga konservasi budaya dan lingkungan, (4). Posisi Bali yang sangat strategis dengan dukungan infratsruktur yang memadai, namun pada era mondial mendatang akan mengalami perubahan fungsi lahan yang apabila tidak dikendalikan melalui perencanaan yang menyeluruh dan integrative dalam satu system akan bermuara pada berbagi kebijakan yang akan menjadi boomerang bagi tujuan pembangunan Bali, dan (5). Di sisi lain, kepentingan dan adanya kewenangan dalam pelekasnaan otonomi daerah yang diartikan secara sempit diperkirakan akan memperkuat ego sektoral yang semata-mata didasari pertumbuhan ekonomi (peningkatan PAD) sehingga persaingan tumbuh akan semakin menghalalkan segala cara, khususnya dalam pemanfaatan sumber daya, terutama lahan dan air. Oleh karena itu perencanaan Bali di masa depan sudah sepatutnya memperhatikan lahandan air yang tersedia untuk dimanfaatkan semaksimal mungkin dengan memperhatikan aspek kelestarian untuk kesejahteraan bersama.

Penelitian Parining (2001) mengenai "Studi tentang Implementasi Konsep Pariwisata Kerakyatan di Bali", menyatakan beberapa pedoman yang bisa dijadikan model pariwisata dan pengembangan di masa depan yaitu: (1). Skala kecil, (2). Kandungan imfornya rendah, (3). Memberdayakan masyarakat local, (4). Bisnisnya ramah lingkungan, (5). Dasar pengembangannnya adalah pengutamaan potensi ecotorism yang dimiliki oleh masing-masing daerah tanpa mengganggu keaslian alam itu sendiri, (6). Masyarakat local sangat "welcome" kepada kepada penduduk pendatang, yang jumlahnya sebaiknya diatur dan tidak terlalu banyak,karena masyarakat local sudah merasa terusik dengan meningkatnya kriminalitas dan mulai 
terganggunya keamanan desa wisata, (7). Belum adanya pemerataan pengetahuan di kalangan fusngsionaris desa mengenai peraturan perundang-undangan tentang kepariwisataan dan peraturan perundang-undangan lainya yang terkait dengan penerapan asas pelestarian lingkungan, (8). Belum adanya pemerataan pengetahuan di kangan pengusaha periwisata mengenai keharusan menerima tenaga kerja setempat sesuai Perda Nomer 8 Tahun 1999, (9). Beluam adanya sangsi yang termuat di dalam kebijakan kepariwisataan bagi pelanggarnya sehingga masyarakat local belum terlindungi haknya, (10). Perlu sosialisasi mengenai ajaran agama Hindu yang sesuai dengan ajaran kitab suci Weda, supaya terjadi keseimbangan antara Tatwa Susila dan Upacara, sehingga tenaga kerja etnis Bali yang beragama Hindu bisa bersaing di tingkat nasional dan internasional, (11). Supaya terjadi pembenahan aturan desa adat yang masih mempunyai aturan "kaku" sehingga bisa menguntungkan semua warga yang mengempon aturan tersebut dan mendorong warganya untuk berprestasi tanpa ketakutan akan kesepekang oleh desa adatnya sendiri (12). Perlu diadakan penyempurnaan Perda Pariwisata Budaya dengan memuat secara konsisten asas-asas pariwisata kerakyatan yang telah tertuang dalam peraturan perundang-perundangan yang lebih tinggi.

Wignjosoebroto (dalam Widodo, 2011: 46) mengemukakan profesionalisme adalah paham yang menciptakan adanya suatu kegiatan kerja di dalam masyarakat. Kegiatan tersebut yakni:

1. Merefleksikan adanya itikad merealisasikan nilai kebajikan yang dijunjung tinggi oleh masyarakat, yang karena itu tidak mengharapkan upah meteriil dari pihak professional pelakunya, melainkan tegaknya kehormatan diri.

2. Dikerjakan berdasarkan kemahiran teknis yang bermutu tinggi, oleh karena itu mensyaratkan adanya pendidikan dan latihan bertahun-tahun secara eksklusif dan berat.

3. Dalam pelaksanannya menundukkan diri pada control sesama yang terorganisasi, berdasarkan kode-kode etik yang dikembangkan dan disepakati bersama dalam organisasi.

Kelompok profesi adalah suatu kelompok yang mendukung kerja yang merefleksikan upaya pengabdian guna merealisaskan nilai-nilai tertentu yang dijunjung tinggi dalam masyarakat sehingga persoalan etika tidak akan pernah lepas dari kehidupan kelompok profesinal tertentu. Kelompok-kelompok professional itu merupakan kelompok yang menguasai memiliki kemahiran untuk menerapkan keahlian tinggi. Hal ini dapat dapat dilakukan lewat pendidikan dan latihan yang sangat berat, lama dan menuntut standar yang tinggi. Semua itu hanya dapat dikontrol dan dinilai "dari dalam" oleh sejawat-sejawatnya (sepadan hidup dan sekeahlian), dengan demikian hadirnya organisasi-organisasi professional akan jelas kian diperlukan.

Pendidikan sebagai investasi (Yusuf, 2011: 96) adalah upaya penanaman modal yang berupa pendidikan yang diharapkan untuk dapat mengahasilkan kembalian lebih banyak pada waktu yang akan datang. Pendidikan sebagai investasi harus dapat memberikan sumbangan dalam kenaikan tingkat kehidupan, kualitas manusia (human 
capital) yang pada gilirannya melahirkan sosial capital dan pendapatan nasional, terutama dalam hal hal berikut:

1. Proses belajar mengajar menjamin masyarakat yang terbuka (yaitu masyarakat yang senantiasa bersedia untuk mempertimbangkan gagasan-gagsan dan harapan baru serta menerima sikap dan proses baru tanpa harus mengorbankan dirinya)

2. System pendidikan harus menyiapkan landasan yang tepat bagi pembangunan dan nilai-nilai riset (jaminan melekat untuk pertumbuhan masyarakat modern yang berkesinambungan). Investasi pendidikan dapat mempertahankan keutuhan dan konstan menambahkan persediaan pengetahuan dan kemungkinan riset dan penemuan metode serta teknik baru yang berkelanjutan.

3. Apabila dalam setiap sector ekonomi didapatkan segala faktor yang dibutuhkan masyarakat, kecuali tenaga kerja yang terampil, maka invesasi dalam sector pendidikan akan menaikkan pendapatan perkapita dalam sector tersebut, kecuali struktur social yang hidup dalam masyarakat tersebut tidak menguntungkan.

4. System pendidikan menciptakan dan mempertahankan penawaran ketrampilan manusia di pasar perburuhan yang luwes dan mampu mengakomodasi dan beradaptasi dalam hubungannya dengan prubahan kebutuhan akan tenaga kerja dan masyarakat teknologi modern yang sedang berubah (sastradipoera, dalam Yusuf, 2011:96)

Pendidikan sebagai investasi memberikan pengaruh terhadap produktifitas suatu negara. Dari pengetahuan keterampilan dan keahlian sesoang sebagai produk pendidikan, akan memiliki kemampuan yang tinggi dalam mencapai tingkat produksi masyarakat. Dengan produksi yang tinggi akan meningkatkan pendapatan masyarakat. Hal ini merupakan suatu indicator adanya pertumbuhan ekonomi suatu negara. Agar produksi yang dihasilkan masyarakat akan menjadi konsumsi yang akan dipertahankan oleh masyarakat, dibutuhkan kemampuan mempertahankan produksi tersebut.

Sebesar apa pun dan sebagus apa pun potensi yang akan menjadi komoditas unggulan jika pelaku usaha pariwisata (desa) tidak siap dengan ilmu manajemen pariwisata, maka bisa dipastikan kegiatan pariwisata itu tak akan berlangsung lama, karena pariwisata dengan segala karakteristiknya tetap diperlukan pengelolaan yang profesional dan inovatif. Termasuk di sini adalah strategi pemasaran yang tepat untuk mengangkat angka kunjungan. Perlu diberikan pelatihan manajemen pariwisata yang sesuai dengan karakteristik desa. Banyak contoh tempat pariwisata yang akhirnya terpuruk, mangkrak karena tidak inovatif sehingga tidak kompetitif, tidak memperhatikan saran dan pendapat pengunjung, tidak ada kelanjutan perbaikan sarana dan prasarana, tidak menangani keluhan pengunjung dan akhirnya pengelola gulung tikar karena rugi (diunduh dari Berdesa.com).

\section{Kesimpulan}

Manfaat pengembangan desa sebagai desa wisata yang tentunya akan langsung memberikan dampak positif bagi warga yaitu tingkat kehidupan warga seperti mampu memunculkan lapangan kerja baru hingga meningkatkan kualitas hidup masyarakat pedesaan melalui fasilitas desa yang diperbaiki agar layak dikunjungi. Selain itu manfaat pengembangan desa sebagai desa wisata lainnya adalah dapat menghidupkan 
budaya, tradisi atau lingkungan adat yang dijiwai oleh agama Hindu sebagai salah satu komoditas wisata budaya lokal yang juga menjaganya agar tetap lestari. Karena umumnya, budaya atau tradisi ini sulit untuk dilestarikan karena mulai hilangnya ketertarikan pada budaya tersebut.

Selain manfaat pengembangan desa sebagai desa wisata dalam hal tingkat hidup masyarakat serta pelestarian budaya, manfaat yang akan diterima oleh masyarakat selanjutnya adalah tentu saja dalam hal perekonomian. Manfaat pengembangan desa sebagai desa wisata di sisi perekonomian secara langsung adalah keuntungan yang diperoleh dari objek wisata yang ditawarkan. Sedangkan untuk manfaat tidak langsungnya adalah meningkatkan kunjungan ke desa sehingga perputaran perekonomian seperti dari hasil penjualan produk lokal bisa semakin lancar atau bahkan dikirim ke luar desa.

Selanjutnya meningkatnya SDM dan SDA, sebagai hasil dari pengembangan desa wisata adalah sebagai sarana promosi produk lokal. Selain meningkatkan pemanfaatan SDA seperti lokasi wisata, keberadaan desa wisata juga dapat memberikan manfaat untuk promosi produk lokal. Manfaat pengembangan desa sebagai desa wisata yang dapat dipaparkan secara langsung, diharapkan warga dapat menerima gambaran singkat bagaimana melalui wawasan baru tersebut serta strategi yang ada dapat meningkatkan kualitas hidup masyarakat pedesaan dan mengembangkan desa ke arah yang lebih baik seperti dari sisi perekonomian.

\section{Daftar Pustaka}

Anom, I Putu, dkk. 2010. Pariwisata Berkelanjutan dalam Pusaran Krisis Global. Denpasar: Udayana University Press.

Astawa, I Nyoman Temon. 2016. "Desa Adat di Bali dalam Tataran Pariwisata Global”. Jurnal Ilmiah Pariwisata Agama dan Budaya. Vol I (2): 2527-9734.

Widodo, Joko. 2011. Membangun Birokrasi Berbasis Kinerja. Malang: Bayumedia Publishing.

Yusuf, Rusli. 2011. Pendidikan dan Investasi Sosial. Bandung: Alfabeta.

https://www.researchgate.net/publication/320327898, Diunduh pada 12 Pebruari 2019.

Prosiding KS: Riset \& PKM volume: 4, Nomor: 1 Hal: 1 - 140, ISSN: 2442-4480.

Modul Daya Tarik Wisata (Mata Kuliah: Pemanduan Wisata Alam dan Ekowisata) Oleh I Ketut Muksin Jurusan Biologi Fakultas Mipa dan Ilmu Pengetahuan Alam Universitas Udayana https://simdos.unud.ac.id/, diunduh pada 12 Pebruari 2019. 
ejournal.lipi.go.id/index.php/jppol/article/download/575/480, diunduh pada 12 Pebruari 2019.

www.berdesa.com. diunduh pada 12 Pebruari 2019. 